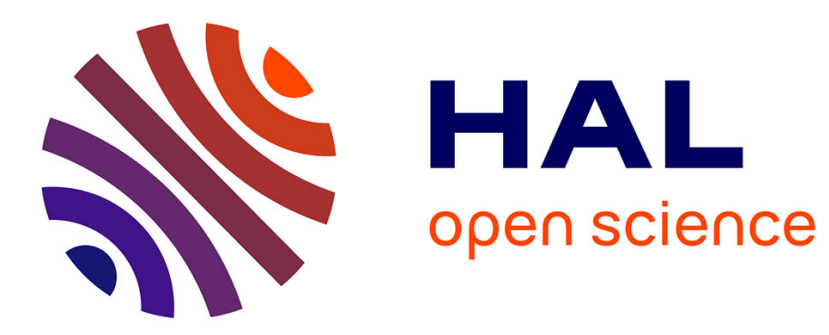

\title{
Neuroimaging biomarkers for Alzheimer's disease in asymptomatic APOE4 carriers.
}

Gaël Chételat, Marine Fouquet

\section{To cite this version:}

Gaël Chételat, Marine Fouquet. Neuroimaging biomarkers for Alzheimer's disease in asymptomatic APOE4 carriers.. Revue Neurologique, 2013, 169 (10), pp.729-36. 10.1016/j.neurol.2013.07.025 . inserm-00909398

\section{HAL Id: inserm-00909398 https://www.hal.inserm.fr/inserm-00909398}

Submitted on 26 Nov 2013

HAL is a multi-disciplinary open access archive for the deposit and dissemination of scientific research documents, whether they are published or not. The documents may come from teaching and research institutions in France or abroad, or from public or private research centers.
L'archive ouverte pluridisciplinaire HAL, est destinée au dépôt et à la diffusion de documents scientifiques de niveau recherche, publiés ou non, émanant des établissements d'enseignement et de recherche français ou étrangers, des laboratoires publics ou privés. 
Neuroimaging biomarkers for Alzheimer's disease in asymptomatic APOE4 carriers

Biomarqueurs de la maladie d'Alzheimer : données en neuroimagerie chez les porteurs APOE4 asymptomatiques 
Gaël Chételat ${ }^{1,2,3,4} \&$ Marine Fouquet ${ }^{1,2,3,4}$

${ }^{1}$ INSERM, U1077, Caen, France

${ }^{2}$ Université de Caen Basse-Normandie, UMR-S1077, Caen, France

${ }^{3}$ Ecole Pratique des Hautes Etudes, UMR-S1077, Caen, France

${ }^{4}$ CHU de Caen, U1077, Caen, France

Corresponding author:

Gaël Chételat, Unité de Recherche U1077, Centre Cyceron, Bd H. Becquerel, BP 5229, 14074 Caen Cedex, France.

e-mail: chetelat@cyceron.fr; Tel: +33 (0)2 314701 73; Fax: +33 (0)2 31470275 


\section{Abstract:}

Introduction. The E4 allele of the apolipoprotein E (APOE4) is the major known genetic risk factor for $\mathrm{AD}$, with a dramatic increase in the risk of developing $\mathrm{AD}$ as the number of APOE4 alleles increases from 0 to 2. For this reason, asymptomatic APOE4 carriers as a group offer a great opportunity to seek for the presence of early biomarkers for $\mathrm{AD}$. The present article reviews neuroimaging studies on APOE4 carriers, focusing on cognitively normal individuals and on the main neuroimaging biomarkers for $\mathrm{AD}$, i.e. atrophy with structural MRI, hypometabolism with FDG-PET, and amyloid deposition with amyloid-PET imaging.

State of art. There is a great number of studies on the effect of APOE4 on brain structures, and they tend to show significant atrophy in APOE4 carriers compared to non carriers especially in regions susceptible to AD pathology such as the hippocampus. However, results are rather discrepant which suggests that the effect of APOE4 on brain structure is subtle. As for FDG-PET metabolism, the few studies show decreased metabolism, again especially in $\mathrm{AD}$-sensitive regions such as posterior associative parietal areas, with a dose-dependent effect (i.e. worsening as the number of APOE4 alleles increases). Finally, there is a unanimous and major effect of APOE4 on amyloid deposition with an increase in A $\beta$ load as the number of APOE4 alleles increases and a decrease in the age of predicted amyloid-positivity in APOE4 carriers. This graded effect of APOE4 on atrophy, hypometabolism, and amyloid deposition is consistent with multimodal neuroimaging studies suggestive of a predominant effect of APOE4 on amyloid rather than tau-related injury and on brain metabolism rather than brain structure. Neuroimaging studies also suggest that APOE4 effects may be mediated by both $\mathrm{A} \beta$-dependent and $\mathrm{A} \beta$-independent pathological processes. This contradicts the view that $\mathrm{A} \beta$ pathology is a necessary upstream event to neuronal injury in $\mathrm{AD}$.

Perspectives and conclusion. Future studies would tell whether the mechanisms and sequences evidenced in carriers is comparable to those found in non carriers, but it is likely that APOE4 not only influences the risk for AD, but also modulates the physiopathological cascade. Altogether, APOE4 carriers offer a great opportunity to investigate brain changes in the asymptomatic stages of $\mathrm{AD}$ and to further our understanding of the physiopathology of the disease, although precaution is needed for interpretation in $\mathrm{AD}$ at large.

Keywords: Apolipoprotein E4, structural MRI, FDG-PET, amyloid PET imaging, preclinical stage, early diagnosis, atrophy 


\section{Résumé :}

Introduction. L'allèle E4 de l'apolipoprotéine E (APOE4) est le plus important facteur de risque génétique pour la maladie d'Alzheimer (MA), avec une augmentation dramatique de ce risque lorsque le nombre d'allèles APOE4 augmente. Les porteurs asymptomatiques de l'allèle APOE4 représentent donc une population particulièrement intéressante pour évaluer, à l'échelle du groupe, la présence de biomarqueurs précoces de la MA. La présente revue, qui correspond à une conférence donnée dans le cadre des Journées Internationales de la Société Française de Neurologie, rapporte les résultats des études d'imagerie chez les porteurs APOE4 en se focalisant uniquement sur les sujets asymptomatiques et en considérant essentiellement les techniques d'imagerie les plus reconnues : l'IRM structurale pour étudier l'atrophie, la TEP-FDG pour le métabolisme et l'imagerie TEP des dépôts amyloïdes.

Etat des connaissances. De très nombreuses études ont évalué les effets de l'APOE4 sur la structure cérébrale. Les résultats sont très divergents, même s'ils suggèrent dans l'ensemble un effet subtile dans le sens d'une diminution de volume dans les régions les plus sensibles à la MA telles que l'hippocampe. Les rares études en TEP-FDG indiquent une baisse du métabolisme là encore dans les régions altérées précocement dans la MA comme le cortex associatif pariétal postérieur, avec un effet dose-dépendant (i.e. fonction du nombre d'allèles APOE4). Enfin, l'effet sur les dépôts amyloïdes est unanime et massif, indiquant une augmentation dose-dépendante chez les porteurs APOE4, et une diminution de l'âge prédit de positivité pour l'amyloïde chez les porteurs. Cet effet graduel de l'APOE4 sur l'atrophie, l'hypométabolisme, puis les dépôts amyloïdes est retrouvé dans les études multimodales qui suggèrent un effet prédominant de l'APOE4 sur les processus amyloïde-dépendants plutôt que tau-dépendants, et sur le métabolisme plutôt que sur la structure. Ces études multimodales, y compris celles réalisées au moyen d'autres techniques d'imagerie, suggèrent également que l'effet de l'APOE4 pourrait être sous-tendu par des processus $A \beta$-dépendants et $A \beta$-indépendants.

Perspectives et conclusion. D'autres études devront être conduites pour déterminer si les mécanismes et la séquence d'événements sont les mêmes chez les porteurs et chez les non porteurs, mais il semble que l'APOE4 n'influence pas uniquement le risque mais pourrait également modifier la cascade d'événements conduisant à la MA. Dans l'ensemble, ces études soulignent l'intérêt des populations APOE4 pour évaluer les changements cérébraux survenant aux stades les plus précoces de la MA, même si toute généralisation des résultats chez les APOE4 à la MA en général doit être considérée avec prudence.

Mots clés : apolipoprotéine E4, IRM structurale, FDG-TEP, imagerie amyloïde, stade préclinique, diagnostic précoce, atrophie 


\section{Introduction}

The apolipoprotein E (ApoE) is a cholesterol carrier glycoprotein that supports lipid transport and injury repair in the brain. The human apolipoprotein E (APOE) gene exists as three polymorphic alleles: $\varepsilon 2, \varepsilon 3$ and $\varepsilon 4$ which have a worldwide frequency of $8 \%, 78 \%$ and $14 \%$, respectively (Schipper, 2011). The $\varepsilon 4$ allele of APOE (APOE4) is the major known genetic risk factor for AD. It has a dosedependent effect on the risk and age at onset of Alzheimer's disease (AD): as the number of alleles increases from 0 to 2, the risk of developing AD increases from 20 to $90 \%$ and the mean age at onset decreases from 84 to 68 years (Corder et al., 1993). More recent estimations reported a lifetime risk of $\mathrm{AD}$ of 50 and $60 \%$ for APOE $4 / 4$ females and males versus $23 \%$ and $30 \%$ for APOE $4 / 3$ males and females, respectively (Genin et al., 2011). A meta-analysis of clinical and autopsy-based studies reported odds ratios for $\mathrm{AD}$ of 2.6, 3.2, and 14.9 for APOE2/4, 3/4, and 4/4, respectively (Farrer et al., 1997). By contrast, the APOE2 allele has a protective effect, with odds ratios of 0.6 for APOE $2 / 3$ or 2/2. It is important to note however that APOE4 is neither necessary nor sufficient to develop AD: there are non carriers amongst AD cases and APOE4 carriers that will not develop AD (Saunders et al., 1993).

Because APOE4 significantly increases the risk of having AD, and consequently because the proportion of individuals who will develop AD is greater amongst APOE4 carriers than amongst non carriers, cognitively normal APOE4 carriers allow to assess the preclinical / asymptomatic stage of the disease. More specifically, by comparing neuroimaging data between carriers and non carriers, one might be able to detect potential early neuroimaging biomarkers of $\mathrm{AD}$ that would be present in asymptomatic stages. The present review is derived from a talk given at the French Society of Neurology aiming at highlighting what APOE4 carriers tell us about neuroimaging biomarkers for AD in the preclinical stage. Therefore, only studies on cognitively normal individuals will be included, focusing on the main neuroimaging biomarkers for $\mathrm{AD}$ considered in the revised criteria for preclinical AD (Dubois et al., 2010; Sperling et al., 2011), i.e. atrophy with structural MRI, hypometabolism with FDG-PET, and $\beta$-amyloid deposition with amyloid-PET imaging, with only brief mention to other imaging modalities.

\section{APOE4 and structural MRI / atrophy}

Studies assessing the effect of APOE4 on brain structure using structural MRI are numerous but lead to diverging findings. Thus, several studies have reported a significant atrophy (or cortical thinning) in APOE4 carriers compared to non carriers, most often in brain regions most susceptible to $A D$, i.e. medial temporal structures (hippocampus, entorhinal cortex, etc; Plassman et al., 1997; Tohgi et al., 1997; Lemaître et al., 2005; Lind et al., 2006; Wishart et al., 2006; Burggren et al., 2008; Honea et al., 
2009; Suthana et al., 2010; O'Dwyer et al., 2012). Other regions are also reported such as the lateral temporal and prefrontal cortex (Wishart et al., 2006) or parietal areas (Honea et al., 2009). Yet, there have also been numerous studies reporting no significant differences between APOE4 carriers and non carriers in terms of brain volume or cortical thickness (Soininen et al., 1995; Schmidt et al., 1996; Reiman et al., 1998; Jack et al., 1998; Cohen et al., 2001; Han et al., 2007; Schuff et al., 2009; Filippini et al., 2009, 2011; Dennis et al., 2010; Kukolja et al., 2010; Liu et al., 2010a; Westlye et al., 2011; Bunce et al., 2012; Protas et al., 2013; Hostage et al., 2013) or even showing greater volume (Honea et al., 2009) or cortical thickness (Espeseth et al., 2008) in APOE4 carriers compared to non carriers. Some studies suggest that the effect of APOE4 is more marked in young that in elderly individuals (Lind et al., 2006; Wishart et al., 2006), but the reverse has also been reported (Mueller et al., 2008; Mueller and Weiner 2009).

Increased rate of atrophy has been shown in APOE4 carriers compared to non carriers in some longitudinal studies, especially in medial temporal structures (Cohen et al., 2001; Chen et al., 2007; Morra et al., 2009; Donix et al., 2010b; Hua et al., 2010; Risacher et al., 2010; Chiang et al., 2011; Lu et al., 2011).

Normal elderly APOE2 carriers were found to show greater cortical thickness in the temporal cortex compared to APOE3 (Fan et al., 2010; Fennema-Notestine et al., 2011) and in the dorsolateral prefrontal cortex compared to APOE4 (Fan et al., 2010), as well as slower rates of hippocampal atrophy compared to APOE3 homozygotes (Chiang et al., 2011) or reduced ventricular expansion (Hua et al., 2008). Yet, again, contradictory findings have been reported, including a lack of difference between APOE2 and APOE 3 in hippocampal volume (Chiang et al., 2010) and cortical thickness (Liu et al., 2010b), or even decreased hippocampal and amygdala volumes in E2 equivalent to that found in E4 carriers (den Heijer et al., 2002), consistent with findings of increased AD neuropathology in APOE2 carriers (Berlau et al., 2009).

Whether these changes represent a genetically-determined feature or is the result of pathological processes is still under debate. The fact that such differences between APOE4 carriers and non carriers have been evidenced in children (Shaw et al., 2007) and even in neonates (Knickmeyer et al., 2013), tends to argue for at least a part of genetic determination. On the other hand, longitudinal studies showed increased rates of atrophy (see above), suggesting that APOE4 also has a pathologic effect that tend to exacerbate with time.

Altogether, these findings suggest that the APOE4 allele may induce changes in the structure of the brain, more particularly in regions susceptible to AD pathology, but that this effect is rather subtle, which would account for the divergence of findings. 


\section{APOE4 and FDG-PET / hypometabolism}

FDG-PET studies investigating the effects of APOE4 are less numerous than those on brain structure but overall the conclusions are similar: in general, studies report a decrease of metabolism in APOE4 carriers compared to non carriers and this decrease mainly concerns AD-sensitive brain areas. The findings are less discrepant than for brain structure - maybe because the effects are more marked on metabolism than on brain structure (see below "multimodality"), or because there are much less PET studies and negative or unexpected results would tend not to be published (see Methodological highlights below).

More specifically, decreased metabolism in APOE4 carriers has first been reported by Small et al., (1995) in elderly with memory complaints and at-least two relatives with AD and by Reiman et al., (1996) in truly cognitively normal elderly. It was found in AD-sensitive regions, i.e. predominantly in posterior cingulate, parietal and temporal areas but also in the prefrontal cortex. Interestingly, the same findings were obtained in young (20-39 years old) carriers (Reiman et al.,, 2004). Moreover a genedose effect was reported in each of these brain regions in late-middle-age individuals, with greater decrease in individuals with two APOE4 alleles compared to those with only one (Reiman et al., 2005). Accelerated rates of decline in resting-state cerebral blood flow in frontal, parietal and temporal cortices have also been reported in one previous study using $\mathrm{H}_{2} \mathrm{O}$-PET (Thambisetty et al., 2010).

Findings obtained with perfusion MRI (an MRI method that measures cerebral blood flow) were however discrepant compared to those with FDG-PET. Thus, one study reported increased perfusion in middle-age APOE4 carriers compared to non carriers (Fleisher et al., 2009), and another laboratory found cingulate cortex dysfunction in elderly but not young carriers (Filippini et al., 2009, 2011). Further studies are needed to directly compare the effects of APOE4 using both techniques on the same sample.

\section{APOE4 and amyloid deposition / amyloid PET imaging}

The effect of APOE on amyloid deposition as assessed with recently developed amyloid-imaging (i.e. PET associated with PIB, florbetapir, or other amyloid ligands) is clearly more unanimous and marked. Thus, APOE4 has been consistently shown in many studies to be associated with a significant increase in $A \beta$ deposition or a greater proportion of amyloid-positive individuals in normal elderly (Reiman et al., 2009; Hinrichs et al., 2010; Morris et al., 2010; Rowe et al., 2010; Villemagne et al., 2011; Jagust et al., 2012; Kantarci et al., 2012; Mathis et al., 2012; Mielke et al., 2012; Fleisher et al., 2013). Thus, across studies in cognitively normal elderly, 35 to $49 \%$ of APOE4 carriers are ${ }^{11}$ C-PIBpositive while they are 9 to $37 \%$ amongst non carriers (see Table 1). Similar findings were obtained 
using FDDNP ligand binding to both NFT and plaques, with increased binding in asymptomatic elderly APOE4 carriers in the frontal cortex (Small et al., 2009).

The effect of APOE on amyloid deposition was found to be dose-dependent, such that PiB increased progressively with each additional E4 allele (Reiman et al., 2009; Morris et al., 2010). This effect is also supposed to be region-specific, i.e. to be more pronounced in some brain regions than in others, but the regions showing a predominant effect differed amongst studies (e.g. the frontal cortex in Reiman et al., 2009 versus posterior regions in Fleisher et al., 2013). Moreover, the presence of the APOE4 allele increases the prevalence of conversion from amyloid-negative to amyloid-positive (Vlassenko et al., 2011) and decreases the age of predicted amyloid-positivity of about 20 years, i.e. from 76 to 56 years in non carriers versus carriers respectively (Fleisher et al., 2013). APOE4 has also been shown to modify the relationships between amyloid deposition and cognitive function, with increased A $\beta$ load being associated with decreased performances especially in APOE4 carriers (Kantarci et al., 2012).

The effect of APOE4 on amyloid imaging thus appears to be marked, unquestionable and consistent amongst study. APOE4 has even been reported to be the best predictor of the presence of amyloid in the brain of healthy elderly amongst age, sex, APOE genotype, family history, or cognitive performance. Yet, it is interesting to note that one study reported that $\mathrm{PiB}$ binding has a high heritability, and $74 \%$ of the heritable component cannot be explained by APOE4 genotype (Hinrichs et al., 2010).

\section{Methodological highlights}

Results are partly discrepant, especially regarding the effect of APOE4 on brain structure. Methodological differences amongst study (e.g. acquisition parameters, quantification methods, etc) may explain part of this variability. Some of the conflicting results may also be attributable to the antagonist pleiotropy of APOE4 effects across different stages of the life span, such that APOE4 may be beneficial in earlier ages and may only confer risk of cognitive decline later in life (Tuminello and Han 2011). It is also possible that non-intuitive findings are not reported and confounding variables are rarely modeled (Donix et al., 2012). Finally, most studies on APOE include individuals with a familial history of $\mathrm{AD}$ which may have blurred the findings as different genetic factors may interact. Thus, APOE genotype and family history risk were shown to have independent and/or additive contribution to structural changes - e.g. hippocampal or precuneus and frontal atrophy (Donix et al., 2010a; Honea et al., 2010; 2011) or metabolism decrease (Mosconi et al., 2007; 2009).

\section{APOE4 effects on other neuroimaging modalities}


While this review primarily focuses on the main recognized neuroimaging biomarkers for $\mathrm{AD}$, namely structural MRI, FDG-PET and amyloid-PET, the effect of APOE4 has also been assessed using other neuroimaging modalities. In brief, the results are consistent with the idea that APOE4 cognitively normal elderly, as a group, do present some signs of AD pathology, e.g. decreased fractional anisotropy as measured with DTI in brain regions usually impaired in AD (Honea et al., 2009), decreased local and regional interconnectivity measured from graph theory applied to fiber tractography data (Brown et al., 2011), or disruption of functional connectivity measured with restingstate fMRI (Sheline et al., 2010). By contrast, a finding often described in fMRI studies of APOE4 carriers is increased activations (often, but not only, within the hippocampus) compared to non carriers in episodic memory tasks (Trachtenberg et al., 2012). For example, Bookheimer et al., (2000) reported an increase in both the magnitude and the extent of brain activation during memory-activation tasks in regions affected by Alzheimer's disease, including the left hippocampal, parietal, and prefrontal regions, in cognitive normal carriers of the APOE4 allele compared to non carriers. This increased activity is usually interpreted as compensatory recruitment to support memory performance, although works in mice suggest that it may rather reflect a detrimental function of hippocampal inhibitory function (Gallagher and Koh, 2011).

\section{Mechanisms and multimodal studies}

Despite the well-documented effect of APOE4, the underlying mechanisms are not completely clear. Postmortem neurohistopathology studies suggest that APOE4 leads to increased production / aggregation of $A \beta$ or decreased clearance. While the effect on amyloid plaque burden is well established, its effect on tau and tau-related mechanisms is much less clear (Kim et al., 2009). Apart from an influence on $\beta$-amyloid pathology, APOE4 may decrease synaptic function, neurogenesis, glucose metabolism, vascular and mitochondrial functions and lipid and cholesterol metabolism, and increase neurotoxicity, aberrant brain activity, brain atrophy and tangle formation (Liu et al., 2013). The review of the literacy from single-modality neuroimaging studies as described above reveals discrepant - and therefore probably subtle - effects of APOE4 on brain structure, less heterogeneous (but rare) findings for FDG-PET, and a clear effect on amyloid deposition, all mainly occurring in AD-sensitive areas. This graded effect of APOE4 on atrophy, hypometabolism, and amyloid deposition, illustrated in Figure 1, is consistent with several results from multimodal neuroimaging studies. It has been shown for example that the effect of APOE4 on A $\beta$ deposition or CSF-A $\beta$ (known to be highly correlated with cortical $A \beta$ deposition) was greater than the effect of the clinical group, while there was a reverse effect for CSF-tau and MRI atrophy (Vemuri et al., 2010; Murphy et al., 2013). Chen et al., (2012) reported that FDG-PET showed a stronger association to APOE4 compared to structural MRI, and concluded that PCC hypometabolism appears earlier than observable MRI- 
based structural abnormalities. Similarly, Protas et al., (2013) found significant differences between APOE4 carriers and non carriers in their posterior cingulate glucose metabolism, but not in their clinical ratings, neuropsychological test scores, hippocampal volumes, or hippocampal glucose metabolism measurements, and they suggest that a reduction in posterior cingulate glucose metabolism precedes a reduction in hippocampal volume or metabolism in cognitively normal persons at increased genetic risk for AD.

In human, it is thought that there are both $\mathrm{A} \beta$-dependant and $\mathrm{A} \beta$-independent effects of APOE4 acting in concert to exacerbate the pathological and clinical phenotypes of AD (Huang, 2010; Liu et al., 2013; see Figure 1). Multimodal studies confirm this view by showing that the effects of APOE4 on brain structure and function is at least partly independent from its effect on amyloid deposition. Thus, Desikan et al., (2013) showed that the APOE4 allele was associated with A $\beta$ deposition but, contrary to CSF-p-tau, didn't affect A $\beta$-associated neurodegeneration in clinically healthy individuals. As another example, comparing cognitively normal APOE4 carriers to non carriers, Sheline et al., (2010) showed decreased resting-state fMRI connectivity in the absence of amyloid plaques or CSF-A $\beta$ abnormalities, suggesting that these changes antedate the pathological effects of fibrillar $A \beta$ deposition. On the same line, Jagust et al., (2012) found an effect of APOE4 on both amyloid deposition and FDG-PET metabolism, but showed that the metabolism decrease was independent from the presence of $A \beta$, concluding that APOE genotype, and not aggregated fibrillar forms of $A \beta$, contributes to reduced glucose metabolism in aging. The detection of APOE4-related structural and functional changes in children (Shaw et al., 2007) or young adults (Filippini et al., 2009), i.e. well before the appearance of $A \beta$ accumulation in the brain, is also suggestive of $A \beta$-independant effects of APOE4. In sum, it is thought that there are both A $\beta$-dependant and A $\beta$ independent effects of APOE4 acting in concert to exacerbate the pathological and clinical phenotypes of AD (Huang 2010; Huang et Mucke 2012).

\section{Conclusion}

Widely accepted neuroimaging biomarkers for AD (hippocampal atrophy, posterior parietal associative cortex hypometabolism and amyloid deposition) can be detected in the asymptomatic stage in APOE4 carriers. There is a graded effect of APOE4 across imaging modalities with a predominant effect on $A \beta$ deposition and more subtle effects on brain structure (Figure 1). Moreover, APOE4 effects seem to be mediated both by $A \beta$-dependent and $A \beta$-independent pathological processes. Future studies would tell whether the mechanisms and sequences evidenced in carriers is comparable to those found in non carriers, but it is likely that APOE4 not only increases the risk for AD, but also modulates its physiopathological cascade. Altogether, APOE4 carriers offer a great opportunity to further our understanding of the physiopathology of the disease, although precaution is needed for interpretation in $\mathrm{AD}$ at large. 
Acknowledgments: The authors thank Renaud Lajoie for providing Table 1.

Conflicts of interest: none to disclose. 


\section{References}

Berlau DJ, Corrada MM, Head E, Kawas CH. APOE epsilon2 is associated with intact cognition but increased Alzheimer pathology in the oldest old. Neurology. 2009; 72(9):829-834.

Bookheimer SY, Strojwas MH, Cohen MS, Saunders AM, Pericak-Vance MA, Mazziotta JC, et al., Patterns of brain activation in people at risk for Alzheimer's disease. N. Engl. J. Med. 2000; 343(7):450-456.

Brown JA, Terashima KH, Burggren AC, Ercoli LM, Miller KJ, Small GW, et al., Brain network local interconnectivity loss in aging APOE-4 allele carriers. Proc. Natl. Acad. Sci. U. S. A. 2011; 108(51):20760-20765.

Bunce D, Anstey KJ, Cherbuin N, Gautam P, Sachdev P, Easteal S. APOE genotype and entorhinal cortex volume in non-demented community-dwelling adults in midlife and early old age. J. Alzheimers Dis. 2012; 30(4):935-942.

Burggren AC, Zeineh MM, Ekstrom AD, Braskie MN, Thompson PM, Small GW, et al., Reduced cortical thickness in hippocampal subregions among cognitively normal apolipoprotein E e 4 carriers. Neuroimage. 2008; 41(4):1177-1183.

Chen K, Ayutyanont N, Langbaum JBS, Fleisher AS, Reschke C, Lee W, et al., Correlations between FDG PET glucose uptake-MRI gray matter volume scores and apolipoprotein E $\varepsilon 4$ gene dose in cognitively normal adults: a cross-validation study using voxel-based multi-modal partial least squares. Neuroimage. 2012; 60(4):2316-2322.

Chen K, Reiman EM, Alexander GE, Caselli RJ, Gerkin R, Bandy D, et al., Correlations between apolipoprotein E epsilon4 gene dose and whole brain atrophy rates. Am. J. Psychiatry. 2007; 164(6):916-921.

Chiang GC, Insel PS, Tosun D, Schuff N, Truran-Sacrey D, Raptentsetsang ST, et al., Hippocampal atrophy rates and CSF biomarkers in elderly APOE2 normal subjects. Neurology. 2010; 75(22):19761981.

Chiang GC, Insel PS, Tosun D, Schuff N, Truran-Sacrey D, Raptentsetsang ST, et al., Impact of apolipoprotein E4-cerebrospinal fluid $\beta$-amyloid interaction on hippocampal volume loss over 1 year in mild cognitive impairment. Alzheimers Dement. 2011; 7(5):514-520.

Cohen RM, Small C, Lalonde F, Friz J, Sunderland T. Effect of apolipoprotein E genotype on hippocampal volume loss in aging healthy women. Neurology. 2001; 57(12):2223-2228.

Corder EH, Saunders AM, Strittmatter WJ, Schmechel DE, Gaskell PC, Small GW, et al., Gene dose of apolipoprotein E type 4 allele and the risk of Alzheimer's disease in late onset families. Science. 1993; 261(5123):921-923.

Dennis NA, Browndyke JN, Stokes J, Need A, Burke JR, Welsh-Bohmer KA, et al., Temporal lobe functional activity and connectivity in young adult APOE varepsilon 4 carriers. Alzheimers Dement. 2010; 6(4):303-311.

Desikan RS, McEvoy LK, Holland D, Thompson WK, Brewer JB, Aisen PS, et al., Apolipoprotein E epsilon4 does not modulate amyloid- $\beta$-associated neurodegeneration in preclinical Alzheimer disease. 
Am. J. Neuroradiol. 2013; 34(3):505-510.

Donix M, Burggren AC, Suthana NA, Siddarth P, Ekstrom AD, Krupa AK, et al., Family history of Alzheimer's disease and hippocampal structure in healthy people. Am. J. Psychiatry. 2010a; 167(11):1399-1406.

Donix M, Burggren AC, Suthana NA, Siddarth P, Ekstrom AD, Krupa AK, et al., Longitudinal changes in medial temporal cortical thickness in normal subjects with the APOE-4 polymorphism. Neuroimage. 2010b; 53(1):37-43.

Donix M, Small GW, Bookheimer SY. Family history and APOE-4 genetic risk in Alzheimer's disease. Neuropsychol. Rev. 2012; 22(3):298-309.

Dubois B, Feldman HH, Jacova C, Cummings JL, Dekosky ST, Barberger-Gateau P, et al., Revising the definition of Alzheimer's disease: a new lexicon. Lancet Neurol. 2010; 9(11):1118-1127.

Espeseth T, Westlye LT, Fjell AM, Walhovd KB, Rootwelt H, Reinvang I. Accelerated age-related cortical thinning in healthy carriers of apolipoprotein E epsilon 4. Neurobiol. Aging. 2008; 29(3):329340.

Fan M, Liu B, Zhou Y, Zhen X, Xu C, Jiang T, et al., Cortical thickness is associated with different apolipoprotein E genotypes in healthy elderly adults. Neurosci. Lett. 2010; 479(3):332-336.

Farrer LA, Cupples LA, Haines JL, Hyman B, Kukull WA, Mayeux R, et al., Effects of age, sex, and ethnicity on the association between apolipoprotein E genotype and Alzheimer disease. A metaanalysis. APOE and Alzheimer Disease Meta Analysis Consortium. J. Am. Med. Assoc. 1997; 278(16):1349-1356.

Fennema-Notestine C, Panizzon MS, Thompson WR, Chen C-H, Eyler LT, Fischl B, et al., Presence of ApoE $\varepsilon 4$ allele associated with thinner frontal cortex in middle age. J. Alzheimers Dis. 2011; 26 Suppl 3:49-60.

Filippini N, Ebmeier KP, MacIntosh BJ, Trachtenberg AJ, Frisoni GB, Wilcock GK, et al., Differential effects of the APOE genotype on brain function across the lifespan. Neuroimage. 2011; 54(1):602-610.

Filippini N, MacIntosh BJ, Hough MG, Goodwin GM, Frisoni GB, Smith SM, et al., Distinct patterns of brain activity in young carriers of the APOE-epsilon4 allele. Proc. Natl. Acad. Sci. U. S. A. 2009; 106(17):7209-7214.

Fleisher AS, Podraza KM, Bangen KJ, Taylor C, Sherzai A, Sidhar K, et al., Cerebral perfusion and oxygenation differences in Alzheimer's disease risk. Neurobiol. Aging. 2009; 30(11):1737-1748.

Fleisher AS, Chen K, Liu X, Ayutyanont N, Roontiva A, Thiyyagura P, et al., Apolipoprotein E $\varepsilon 4$ and age effects on florbetapir positron emission tomography in healthy aging and Alzheimer disease. Neurobiol. Aging. 2013; 34(1):1-12.

Gallagher M, Koh MT. Episodic memory on the path to Alzheimer's disease. Curr. Opin. Neurobiol. 2011; 21(6):929-934.

Genin E, Hannequin D, Wallon D, Sleegers K, Hiltunen M, Combarros O, et al., APOE and Alzheimer 
disease: a major gene with semi-dominant inheritance. Mol. Psychiatry. 2011; 16(9):903-907.

Han SD, Houston WS, Jak AJ, Eyler LT, Nagel BJ, Fleisher AS, et al., Verbal paired-associate learning by APOE genotype in non-demented older adults: fMRI evidence of a right hemispheric compensatory response. Neurobiol. Aging. 2007; 28(2):238-247.

Den Heijer T, Oudkerk M, Launer LJ, van Duijn CM, Hofman A, Breteler MMB. Hippocampal, amygdalar, and global brain atrophy in different apolipoprotein E genotypes. Neurology. 2002; 59(5):746-748.

Hinrichs AL, Mintun MA, Head D, Fagan AM, Holtzman DM, Morris JC, et al., Cortical binding of pittsburgh compound B, an endophenotype for genetic studies of Alzheimer's disease. Biol. Psychiatry. 2010; 67(6):581-583.

Honea RA, Swerdlow RH, Vidoni ED, Burns JM. Progressive regional atrophy in normal adults with a maternal history of Alzheimer disease. Neurology. 2011; 76(9):822-829.

Honea RA, Swerdlow RH, Vidoni ED, Goodwin J, Burns JM. Reduced gray matter volume in normal adults with a maternal family history of Alzheimer disease. Neurology. 2010; 74(2):113-120.

Honea RA, Vidoni E, Harsha A, Burns JM. Impact of APOE on the healthy aging brain: a voxel-based MRI and DTI study. J. Alzheimers Dis. 2009; 18(3):553-564.

Hostage CA, Roy Choudhury K, Doraiswamy PM, Petrella JR, Alzheimer's Disease Neuroimaging Initiative. Dissecting the gene dose-effects of the APOE $\varepsilon 4$ and $\varepsilon 2$ alleles on hippocampal volumes in aging and Alzheimer's disease. Plos One. 2013; 8(2):e54483.

Hua X, Hibar DP, Lee S, Toga AW, Jack CR Jr, Weiner MW, et al., Sex and age differences in atrophic rates: an ADNI study with n=1368 MRI scans. Neurobiol. Aging. 2010; 31(8):1463-1480.

Hua X, Leow AD, Parikshak N, Lee S, Chiang M-C, Toga AW, et al., Tensor-based morphometry as a neuroimaging biomarker for Alzheimer's disease: an MRI study of $676 \mathrm{AD}, \mathrm{MCI}$, and normal subjects. Neuroimage. 2008; 43(3):458-469.

Huang Y. Abeta-independent roles of apolipoprotein E4 in the pathogenesis of Alzheimer's disease. Trends Mol. Med. 2010; 16(6):287-294.

Huang Y, Mucke L. Alzheimer mechanisms and therapeutic strategies. Cell. 2012; 148(6):1204-1222. Jack CR Jr, Petersen RC, Xu YC, O'Brien PC, Waring SC, Tangalos EG, et al., Hippocampal atrophy and apolipoprotein E genotype are independently associated with Alzheimer's disease. Ann. Neurol. 1998; 43(3):303-310.

Jagust WJ, Landau SM, Alzheimer's Disease Neuroimaging Initiative. Apolipoprotein E, not fibrillar $\beta$-amyloid, reduces cerebral glucose metabolism in normal aging. J. Neurosci. 2012; 32(50):1822718233.

Kantarci K, Lowe V, Przybelski SA, Weigand SD, Senjem ML, Ivnik RJ, et al., APOE modifies the association between A $\beta$ load and cognition in cognitively normal older adults. Neurology. 2012; 78(4):232-240.

Kim J, Basak JM, Holtzman DM. The role of apolipoprotein E in Alzheimer's disease. Neuron. 2009; 
63(3):287-303.

Knickmeyer RC, Wang J, Zhu H, Geng X, Woolson S, Hamer RM, et al., Common Variants in Psychiatric Risk Genes Predict Brain Structure at Birth. Cereb. Cortex. 2013.

Kukolja J, Thiel CM, Eggermann T, Zerres K, Fink GR. Medial temporal lobe dysfunction during encoding and retrieval of episodic memory in non-demented APOE epsilon4 carriers. Neuroscience. $2010 ; 168(2): 487-497$.

Lemaître H, Crivello F, Dufouil C, Grassiot B, Tzourio C, Alpérovitch A, et al., No epsilon4 gene dose effect on hippocampal atrophy in a large MRI database of healthy elderly subjects. Neuroimage. 2005; 24(4):1205-1213.

Lind J, Larsson A, Persson J, Ingvar M, Nilsson L-G, Bäckman L, et al., Reduced hippocampal volume in non-demented carriers of the apolipoprotein E epsilon4: relation to chronological age and recognition memory. Neurosci. Lett. 2006; 396(1):23-27.

Liu Y, Paajanen T, Westman E, Wahlund L-O, Simmons A, Tunnard C, et al., Effect of APOE $\varepsilon 4$ allele on cortical thicknesses and volumes: the AddNeuroMed study. J. Alzheimers Dis. 2010a; 21(3):947-966.

Liu Y, Paajanen T, Westman E, Zhang Y, Wahlund L-O, Simmons A, et al., APOE $\varepsilon 2$ allele is associated with larger regional cortical thicknesses and volumes. Dement. Geriatr. Cogn. Disord. 2010 b; 30(3):229-237.

Liu CC, Kanekiyo T, Xu H, Bu G. Apolipoprotein E and Alzheimer disease: risk, mechanisms and therapy. Nat. Rev. Neurol. 2013; 9(2):106-18.

Lu PH, Thompson PM, Leow A, Lee GJ, Lee A, Yanovsky I, et al., Apolipoprotein E genotype is associated with temporal and hippocampal atrophy rates in healthy elderly adults: a tensor-based morphometry study. J. Alzheimers Dis. 2011; 23(3):433-442.

Mathis CA, Kuller LH, Klunk WE, Snitz BE, Price JC, Weissfeld LA, et al., In vivo assessment of amyloid- $\beta$ deposition in nondemented very elderly subjects. Ann. Neurol. 2012;

Mielke MM, Wiste HJ, Weigand SD, Knopman DS, Lowe VJ, Roberts RO, et al., Indicators of amyloid burden in a population-based study of cognitively normal elderly. Neurology. 2012; 79(15):1570-1577.

Morra JH, Tu Z, Apostolova LG, Green AE, Avedissian C, Madsen SK, et al., Automated mapping of hippocampal atrophy in 1-year repeat MRI data from 490 subjects with Alzheimer's disease, mild cognitive impairment, and elderly controls. Neuroimage. 2009; 45(1 Suppl):S3-15.

Morris JC, Roe CM, Xiong C, Fagan AM, Goate AM, Holtzman DM, et al., APOE predicts amyloidbeta but not tau Alzheimer pathology in cognitively normal aging. Ann. Neurol. 2010; 67(1):122-131.

Mosconi L, Brys M, Switalski R, Mistur R, Glodzik L, Pirraglia E, et al., Maternal family history of Alzheimer's disease predisposes to reduced brain glucose metabolism. Proc. Natl. Acad. Sci. U. S. A. 2007; 104(48):19067-19072.

Mosconi L, Mistur R, Switalski R, Brys M, Glodzik L, Rich K, et al., Declining brain glucose 
metabolism in normal individuals with a maternal history of Alzheimer disease. Neurology. 2009; 72(6):513-520.

Mueller SG, Schuff N, Raptentsetsang S, Elman J, Weiner MW. Selective effect of Apo e4 on CA3 and dentate in normal aging and Alzheimer's disease using high resolution MRI at $4 \mathrm{~T}$. Neuroimage. 2008; 42(1):42-48.

Mueller SG, Weiner MW. Selective effect of age, Apo e4, and Alzheimer's disease on hippocampal subfields. Hippocampus. 2009; 19(6):558-564.

Murphy KR, Landau SM, Choudhury KR, Hostage CA, Shpanskaya KS, Sair HI, et al., Mapping the effects of ApoE4, age and cognitive status on 18F-florbetapir PET measured regional cortical patterns of beta-amyloid density and growth. Neuroimage. 2013; 78:474-480.

O’Dwyer L, Lamberton F, Matura S, Tanner C, Scheibe M, Miller J, et al., Reduced hippocampal volume in healthy young ApoE4 carriers: an MRI study. Plos One. 2012; 7(11):e48895.

Plassman BL, Welsh-Bohmer KA, Bigler ED, Johnson SC, Anderson CV, Helms MJ, et al., Apolipoprotein E epsilon 4 allele and hippocampal volume in twins with normal cognition. Neurology. 1997; 48(4):985-989.

Protas HD, Chen K, Langbaum JBS, Fleisher AS, Alexander GE, Lee W, et al., Posterior cingulate glucose metabolism, hippocampal glucose metabolism, and hippocampal volume in cognitively normal, late-middle-aged persons at 3 levels of genetic risk for Alzheimer disease. Jama Neurol. 2013; $70(3): 320-325$.

Reiman EM, Caselli RJ, Yun LS, Chen K, Bandy D, Minoshima S, et al., Preclinical evidence of Alzheimer's disease in persons homozygous for the epsilon 4 allele for apolipoprotein E. N. Engl. J. Med. 1996; 334(12):752-758.

Reiman EM, Chen K, Alexander GE, Caselli RJ, Bandy D, Osborne D, et al., Functional brain abnormalities in young adults at genetic risk for late-onset Alzheimer's dementia. Proc. Natl. Acad. Sci. U. S. A. 2005; 101(1):284-9.

Reiman EM, Chen K, Alexander GE, Caselli RJ, Bandy D, Osborne D, et al., Correlations between apolipoprotein E epsilon4 gene dose and brain-imaging measurements of regional hypometabolism. Proc. Natl. Acad. Sci. U. S. A. 2005; 102(23):8299-8302.

Reiman EM, Chen K, Liu X, Bandy D, Yu M, Lee W, et al., Fibrillar amyloid-beta burden in cognitively normal people at 3 levels of genetic risk for Alzheimer's disease. Proc. Natl. Acad. Sci. U. S. A. 2009; 106(16):6820-6825.

Reiman EM, Uecker A, Caselli RJ, Lewis S, Bandy D, de Leon MJ, et al., Hippocampal volumes in cognitively normal persons at genetic risk for Alzheimer's disease. Ann. Neurol. 1998; 44(2):288-291.

Risacher SL, Shen L, West JD, Kim S, McDonald BC, Beckett LA, et al., Longitudinal MRI atrophy biomarkers: relationship to conversion in the ADNI cohort. Neurobiol. Aging. 2010; 31(8):1401-1418.

Rodrigue KM, Kennedy KM, Devous MD Sr, Rieck JR, Hebrank AC, Diaz-Arrastia R, et al., $\beta$ Amyloid burden in healthy aging: regional distribution and cognitive consequences. Neurology. 2012; 78(6):387-395. 
Rowe CC, Ellis KA, Rimajova M, Bourgeat P, Pike KE, Jones G, et al., Amyloid imaging results from the Australian Imaging, Biomarkers and Lifestyle (AIBL) study of aging. Neurobiol. Aging. 2010; 31(8):1275-1283.

Saunders AM, Schmader K, Breitner JC, Benson MD, Brown WT, Goldfarb L, et al., Apolipoprotein E epsilon 4 allele distributions in late-onset Alzheimer's disease and in other amyloid-forming diseases. Lancet. 1993; 342(8873):710-711.

Schipper HM. Apolipoprotein E: implications for AD neurobiology, epidemiology and risk assessment. Neurobiol. Aging. 2011; 32(5):778-790.

Schmidt H, Schmidt R, Fazekas F, Semmler J, Kapeller P, Reinhart B, et al., Apolipoprotein E e4 allele in the normal elderly: neuropsychologic and brain MRI correlates. Clin. Genet. 1996; 50(5):293-299.

Schuff N, Woerner N, Boreta L, Kornfield T, Shaw LM, Trojanowski JQ, et al., MRI of hippocampal volume loss in early Alzheimer's disease in relation to ApoE genotype and biomarkers. Brain J.

Neurol. 2009; 132(Pt 4):1067-1077.

Shaw P, Lerch JP, Pruessner JC, Taylor KN, Rose AB, Greenstein D, et al., Cortical morphology in children and adolescents with different apolipoprotein E gene polymorphisms: an observational study. Lancet Neurol. 2007; 6(6):494-500.

Sheline YI, Morris JC, Snyder AZ, Price JL, Yan Z, D’Angelo G, et al., APOE4 allele disrupts resting state fMRI connectivity in the absence of amyloid plaques or decreased CSF A $\beta 42$. J. Neurosci. 2010; 30(50):17035-17040.

Small GW, Mazziotta JC, Collins MT, Baxter LR, Phelps ME, Mandelkern MA, et al., Apolipoprotein E type 4 allele and cerebral glucose metabolism in relatives at risk for familial Alzheimer disease. $J$. Am. Med. Assoc. 1995; 273(12):942-947.

Small GW, Ercoli LM, Silverman DH, Huang SC, Komo S, Bookheimer SY, et al., Cerebral metabolic and cognitive decline in persons at genetic risk for Alzheimer's disease. Proc. Natl. Acad. Sci. U. S. A. 2000; 97(11):6037-6042.

Small GW, Siddarth P, Burggren AC, Kepe V, Ercoli LM, Miller KJ, et al., Influence of cognitive status, age, and APOE-4 genetic risk on brain FDDNP positron-emission tomography imaging in persons without dementia. Arch. Gen. Psychiatry. 2009; 66(1):81-87.

Soininen H, Partanen K, Pitkänen A, Hallikainen M, Hänninen T, Helisalmi S, et al., Decreased hippocampal volume asymmetry on MRIs in nondemented elderly subjects carrying the apolipoprotein E epsilon 4 allele. Neurology. 1995; 45(2):391-392.

Sperling RA, Aisen PS, Beckett LA, Bennett DA, Craft S, Fagan AM, et al., Toward defining the preclinical stages of Alzheimer's disease: recommendations from the National Institute on AgingAlzheimer's Association workgroups on diagnostic guidelines for Alzheimer's disease. Alzheimers Dement. 2011; 7(3):280-292.

Suthana NA, Krupa A, Donix M, Burggren A, Ekstrom AD, Jones M, et al., Reduced hippocampal CA2, CA3, and dentate gyrus activity in asymptomatic people at genetic risk for Alzheimer's disease. Neuroimage. 2010; 53(3):1077-1084. 
Thambisetty M, Beason-Held L, An Y, Kraut MA, Resnick SM. APOE epsilon4 genotype and longitudinal changes in cerebral blood flow in normal aging. Arch. Neurol. 2010; 67(1):93-98.

Tohgi H, Takahashi S, Kato E, Homma A, Niina R, Sasaki K, et al., Reduced size of right hippocampus in 39- to 80-year-old normal subjects carrying the apolipoprotein E epsilon4 allele. Neurosci. Lett. 1997; 236(1):21-24.

Trachtenberg AJ, Filippini N, Cheeseman J, Duff EP, Neville MJ, Ebmeier KP, et al., The effects of APOE on brain activity do not simply reflect the risk of Alzheimer's disease. Neurobiol. Aging. 2012; 33(3):618.e1-618.e13.

Tuminello ER, Han SD. The apolipoprotein e antagonistic pleiotropy hypothesis: review and recommendations. Int. J. Alzheimers Dis. 2011; 2011:726197.

Vemuri P, Wiste HJ, Weigand SD, Knopman DS, Shaw LM, Trojanowski JQ, et al., Effect of apolipoprotein $\mathrm{E}$ on biomarkers of amyloid load and neuronal pathology in Alzheimer disease. Ann. Neurol. 2010; 67(3):308-316.

Villemagne VL, Pike KE, Chetelat G, Ellis KA, Mulligan RS, Bourgeat P, et al., Longitudinal Assessment of $A \beta$ and Cognition in Aging and Alzheimer Disease. Ann. Neurol. 2011; 69(1):181192.

Vlassenko AG, Mintun MA, Xiong C, Sheline YI, Goate AM, Benzinger TLS, et al., Amyloid-beta plaque growth in cognitively normal adults: longitudinal [11C]Pittsburgh compound B data. Ann. Neurol. 2011; 70(5):857-861.

Westlye ET, Lundervold A, Rootwelt H, Lundervold AJ, Westlye LT. Increased hippocampal default mode synchronization during rest in middle-aged and elderly APOE $\varepsilon 4$ carriers: relationships with memory performance. J. Neurosci. 2011; 31(21):7775-7783.

Wishart HA, Saykin AJ, McAllister TW, Rabin LA, McDonald BC, Flashman LA, et al., Regional brain atrophy in cognitively intact adults with a single APOE epsilon4 allele. Neurology. 2006; 67(7):1221-1224. 
Table 1: Prevalence of amyloid-positive individuals amongst cognitively normal elderly according to APOE4 status. \% A $\beta+$ : percentage of amyloid-positive individuals; *: mean and/or standard deviation not indicated.

\begin{tabular}{|c|c|c|c|c|c|c|c|}
\hline \multirow[t]{2}{*}{ References } & \multirow[t]{2}{*}{ PET ligand } & \multirow[t]{2}{*}{ Dataset } & \multirow{2}{*}{$\begin{array}{l}\text { Mean age } \\
\text { (standard } \\
\text { deviation) }\end{array}$} & \multicolumn{2}{|c|}{$\begin{array}{c}\text { APOE4 non } \\
\text { carriers }\end{array}$} & \multicolumn{2}{|c|}{$\begin{array}{l}\text { APOE4 } \\
\text { carriers }\end{array}$} \\
\hline & & & & $\mathrm{n}$ & $\% \mathrm{~A} \beta+$ & $\mathrm{n}$ & $\% \mathrm{~A} \beta+$ \\
\hline Rowe et al., 2010 & PIB & AIBL & $71.6(7.4) \mathrm{yrs}$ & 101 & $21 \%$ & 76 & $49 \%$ \\
\hline $\begin{array}{l}\text { Morris et al., } \\
2010\end{array}$ & PIB & $\begin{array}{l}\text { Washington } \\
\text { University }\end{array}$ & 66.8 (10.7) yrs & 158 & $9 \%$ & 83 & $35 \%$ \\
\hline $\begin{array}{l}\text { Jagust et al., } \\
2012\end{array}$ & Florbetapir & ADNI & $77.2(6.0) \mathrm{yrs}$ & 135 & $22 \%$ & 40 & $50 \%$ \\
\hline $\begin{array}{l}\text { Rodrigue et al., } \\
2012\end{array}$ & Florbetapir & $\begin{array}{l}\text { Dallas } \\
\text { lifespan study }\end{array}$ & $\begin{array}{c}>60 * \\
(60 \text { to } 89) \text { yrs }\end{array}$ & 70 & $16 \%$ & 17 & $35 \%$ \\
\hline $\begin{array}{l}\text { Mielke et al., } \\
2012\end{array}$ & PIB & Mayo clinic & $\begin{array}{c}78^{*} \\
(75 \text { to } 82) \mathrm{yrs}\end{array}$ & 361 & $37 \%$ & 122 & $64 \%$ \\
\hline
\end{tabular}




\section{Figure legends}

Figure 1: Schematic representation illustrating the graded effect of APOE4 on amyloid deposition, metabolism and brain structure, showing a clear predominance of its effect on $\mathrm{A} \beta$ pathology (thick arrows). This figure also illustrates that ApoE4 operates through both $A \beta$-dependent and $A \beta$ independent processes. 